\title{
Legislative Election 2019: Overview of the Civil Apparatus Position in Barito Kuala
}

\author{
Andi Tenri Sompa, Muhammad Isa \\ Department of Government Science, \\ Faculty of Social and Political Science, \\ Lambung Mangkurat University, \\ Banjarmasin, Indonesia \\ tenri@ulm.ac.id
}

\begin{abstract}
:
The State Civil Apparatus (ASN) is a vital subject in a country's governance and development system. ASN neutrality in politics is a must. In fact, ASN is often used as a political object from the power of political parties and actors not only at the national but also regional level. This study aims to describe the ASN's political position in the elections in Barito Kuala Regency. As a critical review to explore and build a new paradigm of looking at ASN's political position during the 2019 Legislative Election process in Barito Kuala Regency. A qualitative approach with descriptive methods is used in research. Data collection techniques through three steps, namely: observation, interviews, and documentation. Analysis of Miles and Hubermen's data models and triangulation techniques are used to see the validity of the data. The results of the study are described: (1) The Political Position of ASN in Barito Kuala Regency during the 2019 Legislative Election in some ASNs was still considered to be in favor of one of the legislative candidates. Cases of neutrality violations that occurred in several ASNs, put themselves in a neutral political position. The role of ASN in the formation and distribution of power is only in the voting booth, namely choosing one of the existing legislative candidates. (2) The political position of ASN in Barito Kuala Regency during the 2019 Legislative Election should be able to place itself in a neutral position in accordance with the appeal of the circular letter from MENPAN-RB and the applicable regulations. To build a new paradigm for ASN's political position, the perpetrators of ASN neutrality violations should be fostered because most do not understand their position. For ASN which shows partiality, the organizer (Bawaslu) should take action on this matter.
\end{abstract}

Keywords: political position, civil servants, legislative elections 


\section{INTRODUCTION}

Keywords: Political participation is interpreted as an important aspect of the course of democracy. This assumption underlies democracy (participation) as a person who understands what is good for him or herself is that person. Political decisions made and implemented by the government concern and influence the lives of citizens. Political activities can't run if citizens do not participate in them. Form of activity, political participation requires a group of people to take an active part in political life (Zvulun, Yaakov, \& Harel, 2018). Political participation is not only held by political actors but also all levels of society. The State Civil Apparatus (ASN) is the executive officer for the smooth implementation of government tasks and national development. ASN covers Civil Servants (PNS) and government employees with work agreements (PPPK) who work for government agencies (Contracted Personnel) based on Law Number 5 of 2014 concerning State Civil Apparatus.

In the historical setting of the present Reformation era, the value of ASN neutrality has become an important point in the life of Indonesia's democracy. Points that are always emphasized on ASN ahead of the presidential, legislative and regional head elections. This pressure is due to a bad experience of abuse of ASN power in the New Order (OrdeBaru era) which was not neutral and sided with the authorities (Setiyono, 2016).

Law Number 5 of 2014 concerning State Civil Apparatus, Government Regulation of the Republic of Indonesia Number 42 of 2004 concerning Development of the CorpsSoul and Code of Ethics of Civil Servants, and Government Regulation Number 53 of 2010 concerning Civil Servants of the government limits the power and political rights of ASN. The concept of neutrality values binds ASN to be banned as a member of a political party. This prohibition includes campaign activities, use of state or official facilities for the benefit of groups. In practice, ASN is still given the right to vote on election day.

Nevertheless, the concept of neutrality becomes a homework for the implementation of general elections, especially the Regional Head Election (Pilkada). Based on data collected shows there are 1,256 reports and 878 findings of violations in the elections simultaneously in 2017 (http://KPUsemarangkota.go.id/berita/NETRALITAS-ASN-DALAM-PILKADA-2018, accessed October 21, 2018). violation of ASN neutrality is the subject of government evaluation Concrete government actions in reducing the number of violations of neutrality in the elections through the Ministry of Empowerment of the State Civil Apparatus-Bureaucratic Reform (MENPAN-RB) on December 27, 2017 issued a circular number B/71/M.SM.00.00/2017 concerning Implementation of ASN Neutrality In regard to the MENPAN-RB circular, the implementation of ASN neutrality does not only apply to the 2018 Simultaneous Local Elections, but also applies to the 2019 Legislative Elections and 2019 Presidential and Vice Presidential Elections .

Based on the locus of the study found cases of violation of ASN neutrality during the 2019 legislative election nomination process in Barito Kuala, South Kalimantan (Bawaslu, 2018). The case can be said, bias the concept of neutrality of ASN in political activities in the 2019 Legislative Elections. The case began with HS posting on a personal Facebook account by uploading photos with the background of the banner of the former Barito Kuala regent in two terms nominating as the Regional Representative Council (DPD) RI. The upload was viral enough to attract the attention of the Barito Kuala Panwaslu and was processed by the South Kalimantan Province Election Supervisory Board (BawasluKalsel). This incident finally led to a recommendation for the Regent of Barito Kuala to give sanctions in the form of a warning to HS (http://jejakrekam.com/2018/05/19/patuhi-kasn-bupati-batola-noormiliyani-mengaku-sanksi-hery-

sasmita-cs, accessed 25 October 2018). The complexity of ASN's position in political participation is the focus of this article, especially in Barito Kuala Regency in the 2019 Legislative Election. The purpose of this article is to describe the overall ASN political position in the 2019 Legislative Election in Barito Kuala Regency.

\section{METHODS}

A qualitative approach is used based on consideration in order to explore and understand meaning. The understanding of meaning by individuals or groups of people is ascribed to social or humanitarian problems (Burhan, 2001; Mulyana, 2001). Thus, the qualitative approach is certain to be relevant to the expolaration and in-depth understanding of ASN's political position in Barito Kuala Regency during the 2019

Legislative Election. Descriptive method was chosen to analyze problems related to violations of ASN neutrality in Barito Kuala Regency. The location of the writing is in Barito Kuala Regency, South Kalimantan 
Researchers as human research instruments carry out all stages of research without representation from others (Mulyana, 2001; Denzin \& Lincoln, 2009). The subject of the research was a source of information addressed to key informants, such as: a member of the Barito Kuala Election Commission (KPUD) commissioner, one of the commissioners of the Barito Kuala Regency Election Supervisory Board (Bawaslu), one member of the Barito Regency Regional Representative Council (DPRD) Kuala, one from the general public as well as one person from the political-bureaucratic observer of the government. Data collection techniques include three aspects: 1 ) Observation to observe the behavior and activities of individuals at the location of writing, 2) Interviews with in-depth interviews and structured techniques with open-ended questions, 3) Documentation, namely collecting qualitative documents such as: newspapers, papers, reports,

letters, photographs and other explanations are able to add data. The Miles and Huberman model is used to analyze data: 1) Data reduction is carried out to provide a clearer picture focus, 2) Presentation of data in the form of narrative text exposure, 3) Verification and drawing conclusions raised at an early stage, supported by valid evidence and consistent so the data is credible. Triangulation technique was chosen to check the validity of research data. Comparison of data across data collection techniques such as interviews compared with evaluations of the issuance of the MENPAN-RB circular Number B/71/M.SM.00.00/2017 dated 27 December 2017 concerning the Implementation of ASN Neutrality in 2018 Simultaneous Elections, 2019 Legislative Elections, and Election of President and Vice President in 2019 (Nasution, 2003; Lincoln \& Guba, 1985; Bungin, 2008).

\section{RESULTS AND DISCUSSION}

The legal politics of regulating ASN neutrality is in the context of maintaining integrity, professionalism. This is intended so that the neutrality of ASN can be realized in a democratic local election. Arrangements regarding ASN neutrality are important in order to prevent abuse of authority both by ASN and by regional head candidates. However, this article focuses on the review of ASN's political position in Barito Kuala in the 2019 Legislative Elections. ASN as a profession is inherent to individuals or humans. Humans as fully developed social beings. One influential and has a very important role in human development in modern societies is social organization. According to Joel M. Charon, social organization is a set of patterned social relations (Coleman, 1990). This pattern is formed from the process of social interaction, which develops over time. Patterned social interactions which are also called social organizations are divided into: dyad, group, formal organization, community or society.

Social organizations are usually attached to larger social organizations. The patterns that develop are also influenced by larger groups of social organizations (Berns, 2004). This includes patterns of interaction such as ASN as individuals with the community, which will have a large influence from larger groups such as political parties, community organizations, superiors, incumbents, regional head candidates, legislative candidates, and other interest groups. Social structure, which is a network of question relationships between a number of 'positions' (status positions) of the elements of social organization (Coleman, 1990; Martini, 2012). ASN's position in social structure, placing ASN in an ASN community is expected to behave and relate with others in realizing a democratic life framework. The concept of political position illustrates the position of ASN in Barito Kuala Regency during the 2019 Legislative Election.

ASN's first political position in the social structure that determines where he is in the political community is the Political Role. This position expects the political attitudes of fellow ASNs and towards society to be broadly balanced. Plus the ability of ASN in the formation and distribution of power in Barito Kuala. Based on the conclusions of the interview results, informants from the Election Supervisory Body, the Election Commission, and political-government observers described the role of neutrality that should have been ASN during the 2019 Legislative Elections more broadly. Unlike the understanding of neutrality so far in the community. Trapped in a narrow space, generalizing the neutrality of ASN like the neutrality of the TNIPolri. The neutrality of ASN is very different from the neutrality of the TNI-Polri. ASN still has the right to vote in the ballot box, so ASN is still allowed to attend the campaign. In practice, ASN is still allowed to attend the campaign in official clothing. With the condition that the presence of ASN does not invite one particular candidate to vote.

The second political position of ASN in the social structure is Politic Identity. Identity is formed and changed by the process of socialization. ASN's political identity refers to the ASN's view of himself in dealing with others and society. ASN during the Legislative Election in Barito Kuala Regency in 2019 was identified 
with the identity of power. ASN who is close to DPRD members, leaders of political parties, regional heads who also come from political people; have more access to information about politics. The informant from ASN himself did not reject the people's perception of their closeness to power. Proximity for reasons of the ASN workplace in the DPRD or KPUD; a place where political people meet.

In ordinary people, especially when approaching the elections followed by incumbents. ASN is widely referred to as a person who sided with the authorities. This is because the public has a suspicion that the appointment of ASN in their current position is obtained from the lobby. However, not all ASN sided with the authorities. ASN is still widely found in various institutions that use reasoning to think, who do not think about their personal interests; because ASN is a smart, rational group, with a group with a good level of education.

ASN's third political position in the social structure is Politic Prestige (ASN Politics/Honors). Political prestige/honor can change over time and vary in society. Political prestige/honor is subjective, not everyone considers certain political positions to have high prestige. In the process, the prestigious position of the ASN in the community ultimately depends again on the position or position of the ASN that is carried out. Referring to ASN in the framework of having an organizational unit having a position; shows duties, responsibilities, authority, and rights. Tiered positions from lowest to highest positions. The higher the position, the more authority and rights ASN has. Good positions are in ASN organizational institutions, as well as social organization positions in community groups. As ASN has the position of head of service, head of the division, or religious leaders. So be honored and honored the ASN personally and public views.

ASN's fourth political position in the social structure is Politic Power (Political Power of ASN). Political power, referring to the opportunity to have the will to govern the individuals and groups of subordinates. Seeing how ASN itself influences the attitudes of other people and groups below it. Conducted either by persuasion, threats/sanctions or by physical violence to influence other individuals. During the Legislative Elections in Barito Kuala in 2019, ASN had limitations on power. The limited access to ASN is due to the limited position held. The position in question is the position that shows the duties, responsibilities, authority and rights as an ASN. The greater the position held, the greater the authority and rights possessed by ASN to govern the ASN/working groups under it. Structurally organizational, the power of an ASN official has the power to provide instructions/orders; which in each of these instructions the ASN below it is obliged to obey and carry out the orders of the boss. This is because the ASN institution has a high level of loyalty and compliance with superiors.

The fifth political position of ASN in the social structure is Politic Privileges. Political privilege refers to rights, immunity, or benefits that only a few people enjoy. It can also mean benefits that only one person or group of people has. Political privileges are usually due to certain positions. This can be in the form of material benefits or the right to determine subordinates. The privileges that ASN has in Barito Kuala during the 2019 Legislative Election are reassigned to the position of ASN in structural organizations. The higher the position carried, the more ASN political privileges are obtained. ASN gets special privileges in official events, proximity to leaders and from political parties. However, in the eyes of the law, ideally, ASN has the same position.

The five forms of ASN political position narrowed to two views regarding the role of ASN in legislative elections. First, ASN's neutral political position can be raised when the right to vote is removed (similar to the army and national police now). With a viewpoint, ASN as a civil apparatus, chooses a position as an organizer or citizen. Although this condition will tarnish democracy in Indonesia. Second, the view regarding maintaining the position of ASN as existing positions. ASN position on the basis of the principle of neutrality. The problems that come later, it must be understood that there are many factors that cause ASN to violate its neutrality. Like a sense of security that was not created at ASN during the election period. The new political system, has rejected acts of abuse and shared power with several institutions; not one ruler. ASN is demanded to be neutral, by drawing a dividing line through the rule of law between ASN and politics. As in the rule of law below:

1. Law Number 5 of 2014 concerning State Civil Apparatus, there is the principle of neutrality; that each ASN Employee does not side with any form of influence and does not favor the interests of anyone. ASN's position is clear, ASN employees must be free from the influence and intervention of all parties and political parties. 
2. Law Number 7 of 2017 concerning General Elections, election organizers or campaign teams are prohibited from including ASN as executors and election campaign teams;

3. Government Regulation of the Republic of Indonesia Number 53 Year 2010 concerning Civil Servants. Provide support to candidates for President/Vice President, the House of Representatives, the Regional House of Representatives, or the Regional House of Representatives by: (a) participate as campaign implementers; (b) be a participant in the campaign by using party attributes or civil servant attributes; (c) as a participant in the campaign by deploying other civil servants; and/or (d) as a participant in the campaign using state facilities;

4. Government Regulation of the Republic of Indonesia Number 42 of 2004 Concerning the Development of Civil Servants Corps and Civil Code of Ethics.

Regarding the aforementioned series of regulations, ASN must still be given trust to be able to receive information. Do not reduce the ASN to the state process as a form of carrying out the real substance of democracy. Patalogi or diseases in the body of ASN/bureaucracy will always be in any country. But what must be done is to treat the disease in the sick part only. Likewise with ASN, imposing sanctions on violating ASN. Not by punishing people involved (in not understanding) or revoking all ASN rights. The high level of supervision of Bawaslu and the community has reminded ASN and all parties; that power cannot be used carelessly. There is close supervision of every use of power in the present. Then the prejudice about the strength of identity, power, and privilege of ASN politically like the New Order has been broken.

ASN during the 2019 legislative elections should be brave in every political party campaign as information and reference material to vote later in the voting booth. ASN has the right to vote, so its role in democratic life is to select and choose the best legislative candidates to represent themselves and the people in managing government issues related to legislation, budgets, and oversight. ASN should be given space to find out which candidates are good and not. This is also a form of the role of ASN in the input process. ASN can play a role in giving suggestions and opinions/conveying aspirations to prospective legislators to be processed into a policy or regulation.

\section{CONCLUSION}

Overall, from the key concepts of political position, from identity, prestige, power, to the privileges that the author uses; ASN's position in Barito Kuala Regency in 2019 is still considered strong as an influential position on the formation and distribution of power. This identity is obtained by the writer from the reflection of ASN's own perception and other informants in seeing ASN as people who are professional, intelligent, rational, and have a closeness of power. The Political Position of ASN in Barito Kuala Regency during the 2019 Legislative Election in some ASNs was still considered to be in favor of one legislative candidate. Cases of neutrality violations that occurred in several ASNs, put themselves in a neutral political position. The role of ASN in the formation and distribution of power is only in the voting booth, namely choosing one of the existing legislative candidates. The ASN's political position in Barito Kuala Regency during the 2019 Legislative Election ideally placed itself in a neutral position in accordance with the appeal of the circular letter from the MENPAN-RB and the legislation in force. To build a new paradigm for ASN's political position, the perpetrators of ASN neutrality violations should be fostered because most do not understand their position. For ASN that shows partiality, the organizer (Bawaslu) should follow up on this matter. 
Vol. 6, No. 6, (08-13)

www.ijmas.org

\section{REFERENCES}

1. Bawaslu.2018. Data Badan Pengawas Pemilu. Bawaslu Provinsi Kalimantan Selatan.

2. Berns, R. M. 2004. Child, Family, School, Community: Socialization and Support. 5thed. Forth Worth: Hartcourt Brace College Publishers.

3. Bungin, B. 2008. Analisis Data Penelitian Kualitatif. Jakarta: Raja Grafindo Persada.

4. Burhan, B. 2001. Metodologi Penelitian Kualitatif Aktualisasi Metodologis ke Arah: Ragam Varian Kontemporer. Jakarta : Rajawali Pers.

5. Coleman, J. 1990. Foundations of Social Theory. Cambridge Mass: Harvard University Press.

6. Denzin, N. K., \& Lincoln, Y. S. 2009. HandBook of Qualitative Research. Yogyakarta: Pustaka Pelajar.

7. Lincoln, Y. S., \& Guba, E. G. 1985. Naturalistic Inquiry. California: Sage.

8. Martini, R. 2012. Buku Ajar Birokrasi dan Politik. Semarang: UNDIP Press.

9. Mulyana, D. 2001. Metodelogi Penelitian Kualitatif: Paradigma Baru Ilmu Komunikasi dan Ilmu Sosial Lainnya. Bandung: PT Remaja Rosdakarya.

10. Nasution. 2003. Metode Penelitian Naturalistik Kualitatif. Bandung: Tarsito.

11. Peraturan Pemerintah Republik Indonesia Nomor 53 Tahun 2010 tentang Pegawai Negeri Sipil.

12. Peraturan Pemerintah Republik Indonesia Nomor 42 Tahun 2004 Tentang Pembinaan Jiwa Korps Dan Kode Etik Pegawai Negeri Sipil.

13. Setiyono, B. 2016. Birokrasi dalam Perspektif Politik \& Administrasi. Bandung: Nuansa.

14. Zvulun, Yaakov, J., \& Harel, Y. 2018. Elections as an Opportunity of Learning Civic Education and Political Participation for Teenagers. Citizenship, Social and Economics Education, 136 - 147.

15. Undang-undang Nomor 5 Tahun 2014 tentang Aparatur Sipil Negara.

16. Undang-undang Nomor 7 tahun 2017 tentang Pemilihan Umum.

17. http://KPU-semarangkota.go.id/berita/NETRALITAS-ASN-DALAM-PILKADA-2018 (diakses 21 Oktober 2018).

18. http://jejakrekam.com/2018/05/19/patuhi-kasn-bupati-batola-noormiliyani-mengaku-sudahsanksi-hery-sasmita-cs/ (diakses 25 oktober 2018). 